\title{
Dental Caries Experience among Industrial Workers in Parwanoo, Himachal Pradesh, India
}

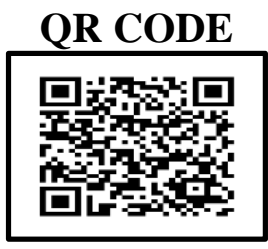

\section{KESARI SINGH*1, ABHINAV BHASKER ${ }^{2}$}

BACKGROUND: Dental caries, the oral disease with multifactorial causes is a major public health problem leading go medically significant morbidity and impacting the general health of a population directly or indirectly. Dental caries is known to affect people from every population.

OBJECTIVE: To assess dental caries experience in permanent dentition among industrial workers in Parwanoo, Himachal Pradesh, India. Materials and Methods: This cross-sectional study was conducted among 1024 industrial workers of Parwanoo, Himachal Pradesh, in the age group of 16-55 years. Dental caries experience was assessed using WHO dentition status proforma (2013). Statistical analysis was done using SPSS 21.0.

RESULTS: Out of 1024 study subjects, 572 were males and 452 were females. Caries prevalence was found to be $47.46 \%$. Mean decaymissing-filled teeth score of the population was $0.95 \pm 0.45$ and was found to be higher among females $(1.06 \pm 0.42)$ as compared to males $(0.93 \pm 0.38)$

CONCLUSION: The prevalence of dental caries in industrial workers is noteworthy. Essential requisites to bring this under control include awareness regarding good dental health, education on prevention of dental caries and implication of necessary measures for the provision of adequate dental care.

KEYWORDS: Caries experience, Dental caries, Industrial Workers

\section{INTRODUCTION}

Dental caries is prevailing across the world and hampering quality of life of those affected. Dental health has been an important part of general health influencing one's personality and is a topic of concern for every individual. Oral diseases are not communicable in nature but still affect almost every population. As dental caries covers a wide spectrum, it won't be wrong to consider it as a major public health issue. The relationship of oral and general health is direct. The outcome of diseases with oro-dental origin rarely results in death or life-threatening conditions but can definitely be attributed the seriousness criteria of being medically significant and may also lead to hospitalisation depending on the grades of severity. No separate allocation of budget for oral health in India, has led to a lag in development of concerned healthcare specialities and oral health status is differing between different populations.

India's economy is highlighting itself on a global basis and has become a business hub for all types of industries. Parwanoo, a municipal council is a small town but leading industrial region of Himachal Pradesh, providing employment to countless workers from all over the country, primarily Northern India. It lies at the border of Himachal Pradesh and Haryana states in the foothills of
Himalayas and has got the biggest wholesale market in Himachal.

Parwanoo is divided into 6 sectors, spread across the Shiwalik range is emerging as the pharmaceutical industrial capital of India. Out of these six sectors, four have got industrial areas. Majority of local population in engaged with the industries in one way or the other. Most of the industries deal with pharmaceuticals, automobile parts, hardware manufacturing, inverters, but also present are a government base food processing unit, cattle feel unit, pesticide unit.

The oral healthcare provision to industrial workers of Parwanoo is limited as there is only one dentist posted at the ESI hospital, no dental college nearby and only two private dental practitioner in town.

To the best of our knowledge, no research work related to oral health has been conducted in Parwanoo city. Hence, the present study was planned and implemented to assess the caries experience in industrial workers of Parwanoo, Himachal Pradesh, India.

\section{MATERIALS AND METHOD}

The present study was conducted on the industrial 
workers of Parwanoo (H.P.) to assess their dental caries experience. The study was systematically scheduled and was spread over a period of 6 months from August 2018 to February 2019, after taking the permission from the Chief Executive Officers of the respective factories. The ethical clearance was taken from the concerned authorities. Examiner were calibrated in the department by the departmental staff prior to the study.

A multistage probability sampling was used. The primary sampling unit consists of four sectors of Parwanoo where industrial units are established. Within each sector, the industries were randomly selected giving equal proportion to small, medium and large scale. A total sample size of 1024 industrial workers within the age group of 16-55 years from the selected industries who have been working in industrial units for at least more than a year and were present on the day of examination were included in the study. Those who were medically compromised, including handicapping conditions, those on long term medication, undergoing orthodontic treatment, not willing to participate in the study and those having any evidence of caries in primary retained teeth were excluded from the study. A detailed weekly and monthly schedule was prepared well in advance by informing and obtaining consent from authorities of respective study areas.

Information regarding demographic details was recorded in a performa and data on caries experience was collected using modified WHO criteria (2013). ${ }^{1}$ The examination of the subjects as per guidelines of American Dental Association for Type III examination was carried out in concerned industrial premises, under natural daylight conditions or using artificial illumination with subjects seated comfortably on ordinary chair with back rest and the examiner sitting in front of them along with a trained recording assistant. Armamentarium used included plane mouth mirror, WHO probe, tweezers, enamel tray, disposable mouth masks, gloves and head caps, cotton holder, proforma sheets, pens, pencils and sterillium.

Statistical Analysis: The data were entered into Microsoft excel and analyzed using SPSS version 21.0 software (SPSS Inc, Chicago, IL, USA). Data was then summarized and presented using descriptive statistics. To find an association between the study variables, chisquare test was used and to compare the mean difference, unpaired t-test and one-way ANOVA were used with a level of significance value set at $\mathrm{P}<0.05$.

\section{RESULTS}

Among the 1024 study subjects, 572 (55.86\%) were males and $452(44.14 \%)$ were females. The number of subjects in the age group of 16-25 year, 26-35 year, 36-45 year and $46-55$ year were $236(23.05 \%), 260(25.39 \%), 250(24.41 \%)$ and $278(27.15 \%)$, respectively. Caries prevalence was found to be $47.46 \%$ (Table 1 ) while mean decay-missingfilled teeth (DMFT) of the population was $0.95 \pm 0.45$. Mean DMFT was found to be higher among females (1.06 $\pm 0.47)$ when compared to males $(0.93 \pm 0.39)$ as seen in table 2 .

\begin{tabular}{|c|c|c|c|c|}
\hline $\begin{array}{c}\text { Age } \\
\text { (years) }\end{array}$ & \multicolumn{2}{|c}{$\begin{array}{c}\text { Total } \\
\text { Males }\end{array}$} & Females & $\begin{array}{c}\text { Caries } \\
(\%)\end{array}$ \\
\hline $16-25$ & 126 & 110 & $\begin{array}{c}236 \\
(23.05)\end{array}$ & 44.45 \\
\hline $26-35$ & 148 & 112 & $\begin{array}{c}260 \\
(25 \cdot 39)\end{array}$ & 44.97 \\
\hline $36-45$ & 140 & 110 & $\begin{array}{c}250 \\
(24.41)\end{array}$ & 48.92 \\
\hline $46-55$ & 158 & 120 & $\begin{array}{c}278 \\
(27.15)\end{array}$ & 51.50 \\
\hline Total & 572 & 452 & $\begin{array}{c}1024 \\
(100.00)\end{array}$ & 47.46 \\
\hline
\end{tabular}

Table 1. Caries prevalence and distribution of subjects according to different age groups (Chi-square value $=6.309, \mathrm{P}=0.095$ )

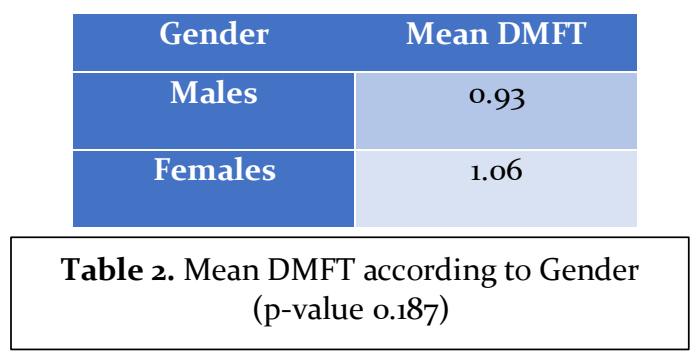

The mean DMFT scores for 16-25 year, 26-35 year, 36-45 year and 46-55 year old industrial workers were found to be $1.03,0.82,0.91$ and 1.11 respectively (Table 3). Highest mean DMFT score was recorded among the 46-55 year old subjects, but the difference between age groups was not found to be statistically significant $(\mathrm{P}=0.078)$.

\section{DISCUSSION}

Dental caries prevalence in our study was found to be 47.46\%. Similar results were obtained by Singh $M$ et al in $2015^{2}$ and Ramya B in 2017. 3 Wide variation of caries Prevalence in this age group has been reported. Our 


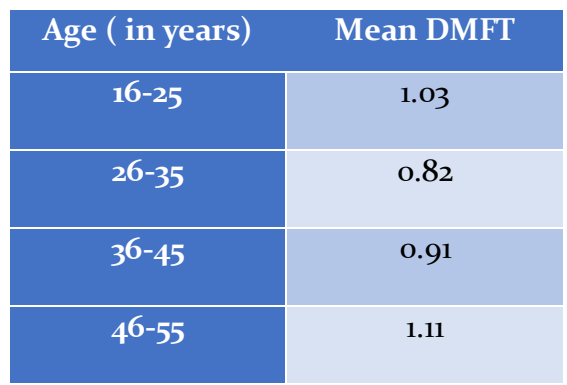

Table 3. Mean DMFT according to Age (p-value 0.078 )

results were not in concordance with the studies conducted by Chatrchaiwiwatana $\mathrm{S}^{4}$ and Grover et al. ${ }^{5}$, which showed a caries prevalence of $60.00 \%$ or more.

Contrasting results have also been reported in research work by Ahlberg J et al. ${ }^{6}$, Duraiswamy et al. ${ }^{7}$ and Sharma A et al. ${ }^{8}$ The difference in variable prevalence may be due to age group and sex taken for the studies, uniformity of selection of the sample, area of study and the type of examination and methodology used for the study. The overall mean DMFT found in our study (0.95) was not in concordance with those reported by Ramya B et al. ${ }^{3}$, Bachanek et al. ${ }^{9}$ and Dagli RJ et al..$^{10}$ This could be due to the fact that our study was conducted in Himachal where the groundwater concentration of fluoride has been reported to be high with a maximum of $1.6 \mathrm{mg} / \mathrm{L}$ reported by Thakur $\mathrm{N}$ et al.11 when compared to the WHO permissible limit of $1.0 \mathrm{mg} / \mathrm{l}^{12}$

Mean DMFT was higher among females (1.06) as compared to males (o.93) which was not statistically significant $(\mathrm{P}=0.187)$. This is in line with the findings of Shaffer JR et al.13, Eustaquio MV et al..$^{14}$ and AlvarezArenal A et al. ${ }^{15}$ This may be due to the fact that teeth erupt earlier in females when compared to males, implicating that female teeth are exposed to the saliva oral environment for a longer duration of time than the males of the same age group. ${ }^{16}$ Higher caries risk in females could also be attributed to fluctuation of hormones. ${ }^{17}$ Mean DMFT score for 16-25, 26-35, 36-45, 46-55 years was found to be 1.03, 0.82, 0.91, 1.11 respectively, but it was not statistically significant $(\mathrm{P}=$ o.078). Increase in caries prevalence with increasing age has also been reported by Duraiswamy et al. ${ }^{7}$, Petersen $\mathrm{PE}^{18}$ and Bernabe $\mathrm{E}$ et al. ${ }^{19}$ The main clause behind this increasing trend in caries with age could be that dental caries is a time intensive and progressive phenomena and the lesion undoubtedly increases over a span of time. As the age increases, people become more independent in their choice of food. Limited use of fluoride containing toothpaste, greater consumption of sugary food and neglect of oral hygiene could also be a reason behind this.

The data evaluated in our study on dental caries experience could help the healthcare professionals to determine the desired treatment planning for industrial workers. The results also indicate a lack of dental care facilities near in the concerned region and give a reflection of the poor oral health status of industrial workers in Parwanoo, Himachal Pradesh. There is a need to frame and effectively imply preventive and curative programs followed by periodic surveys to monitor them accordingly.

\section{CONCLUSION}

The results of the study display a comprehensive evaluation of dental caries experience in a sample of industrial workers. Further emphasis should be laid on effective implementation and evaluation oral health promotion and preventive programs. scarcity of awareness regarding the importance of oral and dental health and inattention in its maintenance are the factors attributable for poor oral health status found among the industrial workers. Hence, there is need to frame and implement essential ways to improve dental of industrial workers, so as to have a healthy productive population for development of our country.

\section{REFERENCES}

1. World Health Organisation. Oral Health Surveys-Basic Methods. $5^{\text {th }}$ ed. Geneva: WHO; 2013.

2. Singh M, Ingle NA, Kaur N, Yadav P, Ingle E, Charania Z. Dental caries status and oral hygiene practices of lock factory workers in Aligarh City. J Int Oral Health. 2015;7(6):57-6o.

3. Ramya B, Reddy CVK. Periodontal status and dental caries experience of granite factory employees in Nanjangud taluk, Mysore. J Indian Assoc Public Health Dent. 2017;9(Suppl 1):364-74.

4. Chatrchaiwiwatana S, Ratanasiri A, Jaidee J, Soontorn S. Factors related to tooth loss due to dental caries among workers in an industrial estates in Thailand. J Med Assoc Thai. 2012 Nov;95 Suppl 11:S1-6.

5. Grover S, Grover R. Assessment of dentition status and treatment needs of bakery workers in Lucknow city. IJOHRR. 2013;1(1):40-6.

6. Ahlberg J, Tuominen R, Murtomaa H. Subsidized dental care improves caries status in male industrial workers. Community Dent Oral Epidemiol 1996;24:249-52. 
7. Duraiswamy P, Kumar TS, Dagli RJ, Chandrakant, Kulkarni S. Dental caries experience and treatment needs of green marble mine laborers in Udaipur district, Rajasthan, India. Indian J Dent Res 2008;19:331-4.

8. Sharma A, Thomas S, Dagli RJ, Solanki J, Arora G, Singh A. Oral health status of cement factory workers, Sirohi, Rajasthan, India. J Health Res Rev. 2014;1(1):15-9. 9. Bachanek T, Pawłowicz A, Tarczydło B, Chalas R. Evaluation of dental health in mill workers. Part I. The state of dentition. Ann Agric Environ Med 2001;8:103-5. 10. Dagli RJ, Kumar S, Dhanni C, Duraiswamy P, Kulkarni S. Dental health among green marble mine laborers, India. J Oral Health Comm Dent. 2008; 2(1): 1-7.

11. Thakur N, Rishi M, Sharma DA, Keesari T (2018) Quality of water resources in Kullu Valley in Himachal Himalayas, India: perspective and prognosis. Appl Water Sci 8(1):20.

12. World Health Organisation. International Standards for Drinking Water. 3rd ed. Geneva: WHO; 1971.

13. Shaffer JR, Leslie EJ, Feingold E, Govil M, McNeil DW, Crout RJ, et al. Caries Experience Differs between
Females and Males across Age Groups in Northern Appalachia. Int J Dent 2015;2015:938213.

14. Eustaquio MV, Montiel JM, Almerich JM. Oral health survey of the adult population of the Valencia region (Spain). Med Oral Patol Oral Cir Bucal. 2010; 15(3): e538544 .

15. Alvarez-Arenal A, Alvarez-Riesgo JA, Pena JM, Fernandez JP, Villa MA. DMFT and treatment needs in adult population ot Oviedo, Spain. Communty Dent Oral Epidemiol. 1996; 24: 17-20.

16. Ur Rehman MM, Mahmood N, Ur Rehman B. The relationship of caries with oral hygiene status and extraoral risk factors 2008;20:103-8.

17. Lukacs JR, Largaespada LL. Explaining sex differences in dental caries prevalence: saliva, hormones, and "lifehistory” etiologies. Am J Hum Biol 2006;18:540-55.

18. Petersen PE. Dental visits, dental health status and need for dental treatment in a Danish industrial population. Scand J Soc Med. 1983;11:59 64.

19. Bernabe E, Sheiham A. Age, period and cohort trends in caries of permanent teeth in four developed countries. Am J Public Health. 2014;104:e115-21.
Source of support: Nil, Conflict of interest: None declared

Cite this article as:

Singh K, Bhasker A. Dental Caries Experience among Industrial Workers in Parwanoo, Himachal Pradesh, India. Int Healthc Res J. 2019;3(4):150-153. https://doi.org/10.26440/IHRJ/0304.07255

\section{AUTHOR AFFILIATIONS:}

Senior Resident, Department of Dentistry, GTB Hospital, Delhi (Corresponding author)

Intern, Swami Devi Dyal Hospital and Dental College, Barwala, Panchkula, India

Address of Corresponding Author:

Dr. Kesari Singh

B-1/27

Delta I

Greater Noida 201308

drkesari241288[at]gmail[dot]com 